\title{
Article \\ Coexisting and Second Primary Cancers in Patients with Uveal Melanoma: A 10-Year Nationwide Database Analysis
}

\author{
Yong Joon Kim ${ }^{1, \dagger}$, Myeongjee Lee ${ }^{2,+}$, Eun Hwa Kim ${ }^{2}$, Inkyung Jung ${ }^{3, *(1)}$ and Christopher Seungkyu Lee ${ }^{1, *}$ \\ 1 Department of Ophthalmology, The Institute of Vision Research, Yonsei University College of Medicine, \\ Seoul 03722, Korea; kyjcolor@yuhs.ac \\ 2 Biostatistics Collaboration Unit, Department of Biomedical Systems Informatics, Yonsei University College of \\ Medicine, Seoul 03722, Korea; mlee1004@yuhs.ac (M.L.); ehkim0607@yuhs.ac (E.H.K.) \\ 3 Division of Biostatistics, Department of Biomedical Systems Informatics, Yonsei University College of \\ Medicine, Seoul 03722, Korea \\ * Correspondence: ijung@yuhs.ac (I.J.); sklee219@yuhs.ac (C.S.L.) \\ + Yong Joon Kim and Myeongjee Lee contributed equally to this work.
}

check for

updates

Citation: Kim, Y.J.; Lee, M.; Kim, E.H.; Jung, I.; Lee, C.S. Coexisting and Second Primary Cancers in Patients with Uveal Melanoma: A 10-Year Nationwide Database Analysis. J. Clin. Med. 2021, 10, 4744. https://doi.org/10.3390/ jcm10204744

Academic Editor: Francisco Javier Ascaso

Received: 2 September 2021 Accepted: 13 October 2021 Published: 15 October 2021

Publisher's Note: MDPI stays neutral with regard to jurisdictional claims in published maps and institutional affiliations.

Copyright: (C) 2021 by the authors. Licensee MDPI, Basel, Switzerland. This article is an open access article distributed under the terms and conditions of the Creative Commons Attribution (CC BY) license (https:// creativecommons.org/licenses/by/ $4.0 /)$.

\begin{abstract}
Uveal melanoma is the most common intraocular tumor in adults. Metastatic disease occurs in about $30 \%$ of patients, for which there is currently no effective treatment. More than half of patients are long-term survivors, and it is well established that cancer survivors are prone to developing second primary cancers. In this study, we analyzed 10 years' worth of data from the nationwide database to determine the rates of coexisting malignancies and second primary cancers associated with uveal melanoma. The mean annual incidence of uveal melanoma was 1.1 per million. Approximately $43 \%$ of patients had coexisting cancers. The most common coexisting cancer was lung cancer $(10 \%)$ followed by liver cancer $(6 \%)$ and non-Hodgkin lymphoma (6\%). In patients whose first cancer in their lifetime was uveal melanoma, the 10-year cumulative incidence of second primary cancers was $22 \%$ (95\% confidence interval, 9-31\%). The age- and sex-adjusted standard incidence rates was 3.61 (95\% confidence interval, 2.61-4.86). The most common second primary cancers were lung cancer and hepatocellular carcinoma, followed by prostate, thyroid, pancreatic, and ovarian cancers. Age was the only factor associated with second primary cancer development. Our findings will be helpful in providing counseling for cancer screening in uveal melanoma patients.
\end{abstract}

Keywords: uveal melanoma; coexisting cancer; second primary cancer; standard incidence rate

\section{Introduction}

Uveal melanoma is the most common intraocular tumor in adults [1,2]. Although several of the signaling pathways involved in uveal melanoma have been discovered, this has not translated into an increase in survival rate [3-7]. While primary uveal melanomas respond well to radiotherapy, liver metastasis occurs in about $30 \%$ of patients, and most patients with metastatic disease die within 2 years [8]. About $70 \%$ of uveal melanoma patients are the long-term survivors [9].

Many cancer survivors have coexisting cancers and second primary cancers (SPCs), a phenomenon ascribed to both environmental factors, such as smoking and occupation, and genetic factors [10-14]. For example, patients with familial adenomatous polyposis frequently develop colon cancer, osteoma, adrenal carcinoma, and thyroid cancer due to the increased $\beta$-catenin activity caused by the APC gene mutation [15-17]. Women positive for the $B R C A 1 / 2$ gene mutation frequently develop hereditary breast and ovarian cancers $[18,19]$. In this context, identifying cancers that accompany uveal melanoma could help to elucidate the underlying mechanism of uveal melanoma and enable counseling provisions for cancer screening.

Previous studies have reported that between $7.7 \%$ and $16.1 \%$ of patients with uveal melanoma develop SPCs including skin, kidney, breast, and prostate cancers [20-23]. 
Most of these studies were published before 2010, thus the incidence may have been underestimated considering the subsequent development of cancer screening methods. In South Korea, a national cancer screening program was introduced in 1999 and was expanded upon thereafter. This program enables the more accurate analysis of the incidence of coexisting cancers and SPCs. In this study, we analyzed 10 years' worth of data from this nationwide database to determine the rates of coexisting malignancies and SPCs associated with uveal melanoma.

\section{Materials and Methods}

\subsection{Data Sources}

This was a nationwide, retrospective, cohort study based on the Korean Health Insurance and Review Assessment (HIRA) database, which comprises nationwide health insurance claim data covering approximately $98 \%$ of the total population of Korea and including the general characteristics of the beneficiaries as well as all diagnoses, procedures, treatments received in health care services, and inpatient and outpatient prescriptions [24]. In the HIRA database, all beneficiary and health care provider identifications are encrypted according to the Health Insurance Portability and Accountability Act privacy rule to protect personal information, and diagnoses are coded based on the International Classification of Diseases 10th Revision (ICD-10). This study was approved by the Institutional Review Board (IRB)/Ethics Committee of Severance Hospital, Yonsei University Health System (IRB No. 4-2019-0618), which also waived the requirement for informed patient consent due to the retrospective study design and use of de-identified data.

\subsection{Study Population}

Uveal melanoma patients are defined by ICD-10 code C69.3 or C69.4 as the principal or first additional diagnosis with codes for expanding benefit coverage (V-code in Korea). Policies to expand benefit coverage commenced in 2005 and have reduced the medical expenses for catastrophic illnesses, such as cancer and cardiocerebrovascular diseases [25]. During the study period (January 2008 to December 2018), 702 patients with uveal melanoma were identified. A 1-year washout period was applied to exclude prevalent uveal melanoma cases $(n=123)$. We further excluded seven patients with a diagnosis of retinoblastoma as the primary cancer. Therefore, 572 uveal melanoma patients were included in the analyses.

\subsection{Definition of Coexisting Cancer and SPC}

The objectives of this study were to identify coexisting cancers accompanying uveal melanoma and to determine the incidence of SPC in patients with uveal melanoma. Coexisting cancer was defined as any malignancy diagnosed prior to or after the diagnosis of uveal melanoma. SPCs were evaluated among patients diagnosed with uveal melanoma as the first cancer in their lifetime. We defined SPC as any cancer that developed at least 6 months after the date of uveal melanoma diagnosis. In these two analyses, skin melanoma (C43), ocular tumors (C69), and secondary cancers in which the involved site was not specified (C77-80) were not considered events of interest. Hematological cancers included Hodgkin lymphoma (C81), non-Hodgkin lymphoma (C82-86 and C97), multiple myeloma (C90), and leukemia (C91-95). Head and neck cancers included palate (C5), mouth (C6), parotid gland (C7), unspecified major salivary gland (C8), tonsil (C9), oropharynx (C10), nasopharynx (C11), unspecified lip, oral cavity, and pharynx (C14), and nasal cavity and middle ear (C30) cancers.

\subsection{Statistical Analysis}

Continuous variables were presented as mean \pm standard deviation, and categorical variables are presented as frequencies and their percentages. Age at uveal melanoma diagnosis and the trend of the incidence rate of uveal melanoma during the study period were examined using a linear regression model. In the SPC analysis, only patients diagnosed with uveal melanoma as the primary cancer were included. These uveal melanoma patients 
were followed up from the date of uveal melanoma diagnosis to the date of SPC diagnosis (event of interest), death, or the end of the study (31 December 2018), whichever came first. The Kaplan-Meier method was used to estimate the cumulative incidence of SPC in uveal melanoma patients. To investigate a potentially increased risk of SPC in uveal melanoma patients compared to the general population, we calculated the standardized incidence ratio (SIR) as the ratio of the numbers of observed to expected cases. The expected number of cancer cases was calculated as the 5-year age-specific standard incidence rates (SIR) for the general population multiplied by the person-years of uveal melanoma patients, using the cancer incidence rates from 2014 reported by the Korea Central Cancer Registry [26]. The $95 \%$ confidence intervals (CIs) of the SIR were calculated using the Poisson distribution. We then assessed the associations of age at uveal melanoma diagnosis, sex, and enucleation with the development of SPC using a Cox proportional hazard regression model. Enucleation was considered a time-varying risk factor. We further implemented the Fine and Gray model to consider death as a competing risk [27]. For each risk factor, we implemented a univariate model first and further investigated the association after adjusting for other risk factors. The results are presented as hazard ratios (HRs) with $95 \%$ CIs. In all of the analyses, a two-sided $p$-value $<0.05$ was taken to indicate statistical significance. SAS Enterprise Guide version 9.4 (SAS Institute Inc., Cary, NC, USA) and R 3.6.1 (R Foundation for Statistical Computing, Vienna, Austria) were used for all statistical analyses.

\section{Results}

\subsection{Incidence of Uveal Melanoma}

Between January 2008 and December 2018, 702 patients were diagnosed with uveal melanoma and were registered as cancer patients. After the application of a 1-year washout period, 572 patients were included in the analysis. The median age (interquartile range of the 297 (52\%) male and 275 (48\%) female patients) was 57 (47-67) years of age (Figure 1A). The mean annual incidence rate of disease was 1.1 (range $0.9-1.5)$ per 1,000,000 people and exhibited an increasing trend over time, but this was not statistically significant (Figure 1B). Among the 572 patients, 501 (88\%) and 71 (12\%) had choroidal (C69.3) and ciliary body (C69.4) tumors, respectively. During the study period, 352 patients were diagnosed with uveal melanoma as their first cancer.

A

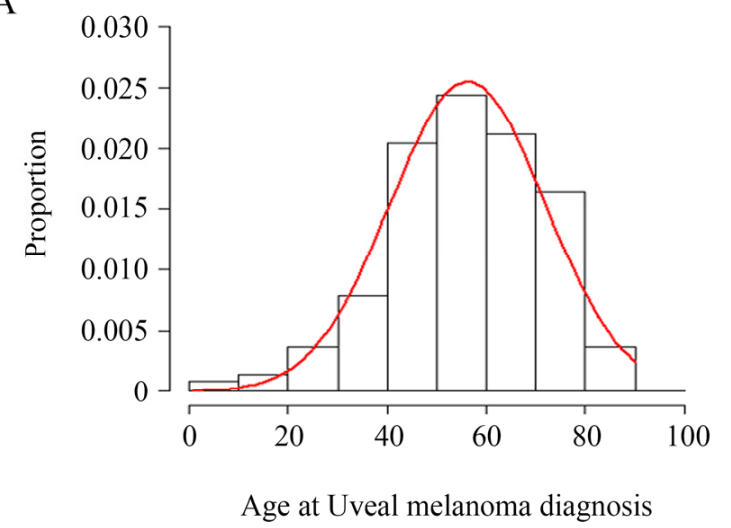

B

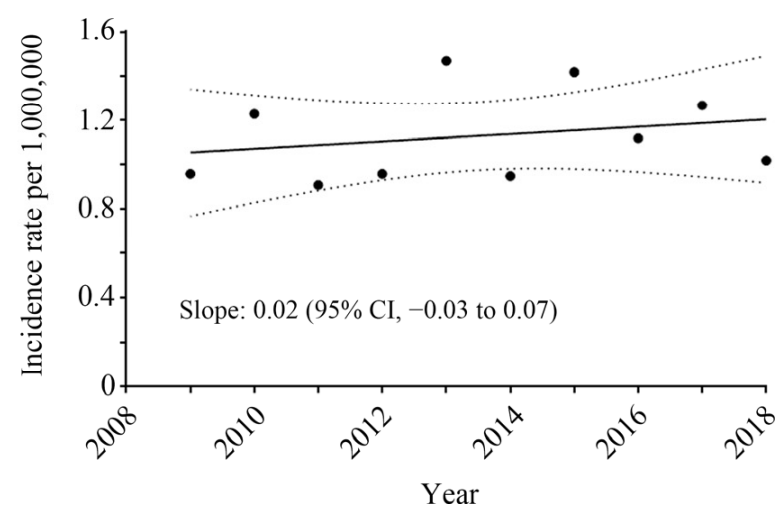

Figure 1. (A) Age distribution at diagnosis and (B) the annual incidence of uveal melanoma in Korea.

\subsection{Coexisting Cancers in Patients with Uveal Melanoma}

After excluding melanoma and ocular tumors, 245 (43\%) patients were found to have coexisting cancers. Among them, 155 had one coexisting cancer, and 90 had two or more coexisting cancers. The 381 coexisting tumors could be grouped into 51 types of cancers, the most common of which was lung cancer in $58(10.1 \%)$ patients, followed by liver, breast, brain, prostate, and thyroid cancers (Table 1). The coexisting hematological cancers were non-Hodgkin lymphoma in $32(6 \%)$ patients and Hodgkin lymphoma in $4(1 \%)$ patients. 
There were no patients with leukemia or multiple myeloma. Head and neck cancers were diagnosed in 20 patients.

Table 1. Coexisting cancers associated with uveal melanoma.

\begin{tabular}{|c|c|c|c|c|c|}
\hline $\begin{array}{l}\text { ICD-10 } \\
\text { Code }\end{array}$ & Tissue & $n(\%)$ & $\begin{array}{l}\text { ICD-10 } \\
\text { Code }\end{array}$ & Tissue & $n(\%)$ \\
\hline C34 & $\begin{array}{l}\text { Malignant neoplasm } \\
\text { of bronchus and lung }\end{array}$ & $\begin{array}{c}58 \\
(10.1 \%)\end{array}$ & C82 & Follicular lymphoma & $\begin{array}{c}3 \\
(0.5 \%)\end{array}$ \\
\hline $\mathrm{C} 22$ & $\begin{array}{l}\text { Malignant neoplasm } \\
\text { of liver and } \\
\text { intrahepatic bile ducts }\end{array}$ & $\begin{array}{c}36 \\
(6.3 \%)\end{array}$ & $\mathrm{C} 20$ & $\begin{array}{l}\text { Malignant neoplasm } \\
\text { of rectum }\end{array}$ & $\begin{array}{c}3 \\
(0.5 \%)\end{array}$ \\
\hline $\mathrm{C} 71$ & $\begin{array}{c}\text { Malignant neoplasm } \\
\text { of brain }\end{array}$ & $\begin{array}{c}27 \\
(4.7 \%)\end{array}$ & C70 & $\begin{array}{l}\text { Malignant neoplasm } \\
\text { of meninges }\end{array}$ & $\begin{array}{c}2 \\
(0.3 \%)\end{array}$ \\
\hline C50 & $\begin{array}{c}\text { Malignant neoplasm } \\
\text { of breast }\end{array}$ & $\begin{array}{c}27 \\
(4.7 \%)\end{array}$ & $\mathrm{C} 40$ & $\begin{array}{l}\text { Malignant neoplasm } \\
\text { of bone and articular } \\
\text { cartilage of limbs }\end{array}$ & $\begin{array}{c}2 \\
(0.3 \%)\end{array}$ \\
\hline C61 & $\begin{array}{l}\text { Malignant neoplasm } \\
\text { of prostate }\end{array}$ & $\begin{array}{c}24 \\
(4.2 \%)\end{array}$ & C38 & $\begin{array}{l}\text { Malignant neoplasm } \\
\text { of heart, mediastinum } \\
\text { and pleura }\end{array}$ & $\begin{array}{c}2 \\
(0.3 \%)\end{array}$ \\
\hline C73 & $\begin{array}{l}\text { Malignant neoplasm } \\
\text { of thyroid gland }\end{array}$ & $\begin{array}{c}23 \\
(4.0 \%)\end{array}$ & $\mathrm{C} 37$ & $\begin{array}{l}\text { Malignant neoplasm } \\
\text { of thymus }\end{array}$ & $\begin{array}{c}2 \\
(0.3 \%)\end{array}$ \\
\hline C16 & $\begin{array}{l}\text { Malignant neoplasm } \\
\text { of stomach }\end{array}$ & $\begin{array}{c}17 \\
(3.0 \%)\end{array}$ & C30 & $\begin{array}{c}\text { Malignant neoplasm } \\
\text { of nasal cavity and } \\
\text { middle ear }\end{array}$ & $\begin{array}{c}2 \\
(0.3 \%)\end{array}$ \\
\hline C85 & $\begin{array}{c}\text { Other and unspecified } \\
\text { types of non-Hodgkin } \\
\text { lymphoma }\end{array}$ & $\begin{array}{c}16 \\
(2.8 \%)\end{array}$ & $\mathrm{C} 08$ & $\begin{array}{l}\text { Malignant neoplasm } \\
\text { of other and } \\
\text { unspecified major } \\
\text { salivary glands }\end{array}$ & $\begin{array}{c}2 \\
(0.3 \%)\end{array}$ \\
\hline $\mathrm{C} 44$ & $\begin{array}{l}\text { Other malignant } \\
\text { neoplasms of skin }\end{array}$ & $\begin{array}{c}16 \\
(2.8 \%)\end{array}$ & C96 & $\begin{array}{l}\text { Other and unspecified } \\
\text { malignant neoplasms } \\
\text { of lymphoid, } \\
\text { haematopoietic, and } \\
\text { related tissue }\end{array}$ & $\begin{array}{c}1 \\
(0.2 \%)\end{array}$ \\
\hline $\mathrm{C} 25$ & $\begin{array}{l}\text { Malignant neoplasm } \\
\text { of pancreas }\end{array}$ & $\begin{array}{c}10 \\
(1.7 \%)\end{array}$ & $\mathrm{C} 86$ & $\begin{array}{c}\text { Other specified types } \\
\text { of } \mathrm{T} / \mathrm{NK} \text {-cell } \\
\text { lymphoma }\end{array}$ & $\begin{array}{c}1 \\
(0.2 \%)\end{array}$ \\
\hline $\mathrm{C} 83$ & $\begin{array}{l}\text { Non-follicular } \\
\text { lymphoma }\end{array}$ & $\begin{array}{c}9 \\
(1.6 \%)\end{array}$ & C75 & $\begin{array}{c}\text { Malignant neoplasm } \\
\text { of other endocrine } \\
\text { glands and related } \\
\text { structures }\end{array}$ & $\begin{array}{c}1 \\
(0.2 \%)\end{array}$ \\
\hline $\mathrm{C} 72$ & $\begin{array}{l}\text { Malignant neoplasm } \\
\text { of spinal cord, cranial } \\
\text { nerves and other parts } \\
\text { of central nervous } \\
\text { system }\end{array}$ & $\begin{array}{c}8 \\
(1.4 \%)\end{array}$ & C62 & $\begin{array}{c}\text { Malignant neoplasm } \\
\text { of testis }\end{array}$ & $\begin{array}{c}1 \\
(0.2 \%)\end{array}$ \\
\hline $\mathrm{C} 18$ & $\begin{array}{l}\text { Malignant neoplasm } \\
\text { of colon }\end{array}$ & $\begin{array}{c}8 \\
(1.4 \%)\end{array}$ & C57 & $\begin{array}{l}\text { Malignant neoplasm } \\
\text { of other and } \\
\text { unspecified female } \\
\text { genital organs }\end{array}$ & $\begin{array}{c}1 \\
(0.2 \%)\end{array}$ \\
\hline $\mathrm{C} 76$ & $\begin{array}{l}\text { Malignant neoplasm } \\
\text { of other and } \\
\text { ill-defined sites }\end{array}$ & $\begin{array}{c}7 \\
(1.2 \%)\end{array}$ & C54 & $\begin{array}{l}\text { Malignant neoplasm } \\
\text { of corpus uteri }\end{array}$ & $\begin{array}{c}1 \\
(0.2 \%)\end{array}$ \\
\hline C49 & $\begin{array}{l}\text { Malignant neoplasm } \\
\text { of other connective } \\
\text { and soft tissue }\end{array}$ & $\begin{array}{c}7 \\
(1.2 \%)\end{array}$ & $\mathrm{C} 53$ & $\begin{array}{l}\text { Malignant neoplasm } \\
\text { of cervix uteri }\end{array}$ & $\begin{array}{c}1 \\
(0.2 \%)\end{array}$ \\
\hline C41 & $\begin{array}{l}\text { Malignant neoplasm } \\
\text { of bone and articular } \\
\text { cartilage of other and } \\
\text { unspecified sites }\end{array}$ & $\begin{array}{c}6 \\
(1.0 \%)\end{array}$ & C14 & $\begin{array}{l}\text { Malignant neoplasm } \\
\text { of other and } \\
\text { ill-defined sites in the } \\
\text { lip, oral cavity, and } \\
\text { pharynx }\end{array}$ & $\begin{array}{c}1 \\
(0.2 \%)\end{array}$ \\
\hline
\end{tabular}


Table 1. Cont.

\begin{tabular}{|c|c|c|c|c|c|}
\hline $\begin{array}{l}\text { ICD-10 } \\
\text { Code }\end{array}$ & Tissue & $n(\%)$ & $\begin{array}{l}\text { ICD-10 } \\
\text { Code }\end{array}$ & Tissue & $n(\%)$ \\
\hline C31 & $\begin{array}{l}\text { Malignant neoplasm } \\
\text { of accessory sinuses }\end{array}$ & $\begin{array}{c}6 \\
(1.0 \%)\end{array}$ & C32 & $\begin{array}{l}\text { Malignant neoplasm } \\
\text { of larynx }\end{array}$ & $\begin{array}{c}1 \\
(0.2 \%)\end{array}$ \\
\hline C67 & $\begin{array}{l}\text { Malignant neoplasm } \\
\text { of bladder }\end{array}$ & $\begin{array}{c}5 \\
(0.9 \%)\end{array}$ & $\mathrm{C} 24$ & $\begin{array}{l}\text { Malignant neoplasm } \\
\text { of other and } \\
\text { unspecified parts of } \\
\text { biliary tract }\end{array}$ & $\begin{array}{c}1 \\
(0.2 \%)\end{array}$ \\
\hline C64 & $\begin{array}{c}\text { Malignant neoplasm } \\
\text { of kidney, except renal } \\
\text { pelvis }\end{array}$ & $\begin{array}{c}5 \\
(0.9 \%)\end{array}$ & $\mathrm{C} 17$ & $\begin{array}{l}\text { Malignant neoplasm } \\
\text { of small intestine }\end{array}$ & $\begin{array}{c}1 \\
(0.2 \%)\end{array}$ \\
\hline C56 & $\begin{array}{l}\text { Malignant neoplasm } \\
\text { of ovary }\end{array}$ & $\begin{array}{c}5 \\
(0.9 \%)\end{array}$ & C15 & $\begin{array}{l}\text { Malignant neoplasm } \\
\text { of oesophagus }\end{array}$ & $\begin{array}{c}1 \\
(0.2 \%)\end{array}$ \\
\hline C11 & $\begin{array}{l}\text { Malignant neoplasm } \\
\text { of nasopharynx }\end{array}$ & $\begin{array}{c}5 \\
(0.9 \%)\end{array}$ & C33 & $\begin{array}{l}\text { Malignant neoplasm } \\
\text { of trachea }\end{array}$ & $\begin{array}{c}1 \\
(0.2 \%)\end{array}$ \\
\hline $\mathrm{C} 07$ & $\begin{array}{l}\text { Malignant neoplasm } \\
\text { of parotid gland }\end{array}$ & $\begin{array}{c}5 \\
(0.9 \%)\end{array}$ & $\mathrm{C} 10$ & $\begin{array}{l}\text { Malignant neoplasm } \\
\text { of oropharynx }\end{array}$ & $\begin{array}{c}1 \\
(0.2 \%)\end{array}$ \\
\hline C88 & $\begin{array}{c}\text { Malignant } \\
\text { immunoproliferative } \\
\text { diseases }\end{array}$ & $\begin{array}{c}4 \\
(0.7 \%)\end{array}$ & C09 & $\begin{array}{l}\text { Malignant neoplasm } \\
\text { of tonsil }\end{array}$ & $\begin{array}{c}1 \\
(0.2 \%)\end{array}$ \\
\hline C81 & Hodgkin lymphoma & $\begin{array}{c}4 \\
(0.7 \%)\end{array}$ & C06 & $\begin{array}{l}\text { Malignant neoplasm } \\
\text { of other and } \\
\text { unspecified parts of } \\
\text { mouth }\end{array}$ & $\begin{array}{c}1 \\
(0.2 \%)\end{array}$ \\
\hline $\mathrm{C} 74$ & $\begin{array}{l}\text { Malignant neoplasm } \\
\text { of adrenal gland }\end{array}$ & $\begin{array}{c}4 \\
(0.7 \%)\end{array}$ & $\mathrm{C} 05$ & $\begin{array}{l}\text { Malignant neoplasm } \\
\text { of palate }\end{array}$ & $\begin{array}{c}1 \\
(0.2 \%)\end{array}$ \\
\hline C19 & $\begin{array}{c}\text { Malignant neoplasm } \\
\text { of rectosigmoid } \\
\text { junction }\end{array}$ & $\begin{array}{c}4 \\
(0.7 \%)\end{array}$ & & & \\
\hline
\end{tabular}

\subsection{SPC in Patients with Uveal Melanoma}

Among the 352 patients for whom uveal melanoma was the first cancer diagnosis, $43(12 \%)$ developed SPCs, of which there were 15 different types (Table 2). The 10-year cumulative incidence of SPCs was $22 \%(95 \%$ CI, 9-31) (Figure 2). The age- and sex-adjusted SIR was 3.61 (95\% CI, 2.61-4.86, $p<0.001)$, indicating a significantly higher overall cancer risk in patients with uveal melanoma than in the general population. Data on the observed and expected cases are presented in Table 3. The most common SPCs were lung cancer (9 patients) and hepatocellular carcinoma (9 patients) followed by prostate (5 patients), thyroid (4 patients), pancreatic ( 3 patients), and ovarian (3 patients) cancer. Most cases of liver, pancreatic, lung, and thyroid cancer developed within the first 2 years after the diagnosis of uveal melanoma. Prostate and ovarian cancers developed after an average of 3.2 (range, 0.8-8.7) and 5.0 (range, 1.4-6.9) years, respectively.

Table 2. Second primary cancers associated with uveal melanoma.

\begin{tabular}{ccc}
\hline $\begin{array}{c}\text { ICD-10 } \\
\text { Code }\end{array}$ & Tissue & $n(\mathbf{\%})$ \\
\hline C34 & Malignant neoplasm of bronchus and lung & 9 \\
& & $(2.6 \%)$ \\
C22 & Malignant neoplasm of liver and intrahepatic bile ducts & 9 \\
& & $(2.6 \%)$ \\
C61 & Malignant neoplasm of prostate & 5 \\
& Malignant neoplasm of thyroid gland & $(1.4 \%)$ \\
C73 & Malignant neoplasm of pancreas & 4 \\
& & $(1.1 \%)$ \\
& & 3 \\
& & $(0.9 \%)$ \\
\hline
\end{tabular}


Table 2. Cont.

\begin{tabular}{|c|c|c|}
\hline $\begin{array}{c}\text { ICD-10 } \\
\text { Code }\end{array}$ & Tissue & $n(\%)$ \\
\hline C56 & Malignant neoplasm of ovary & $\begin{array}{c}3 \\
(0.9 \%)\end{array}$ \\
\hline $\mathrm{C} 71$ & Malignant neoplasm of brain & $\begin{array}{c}2 \\
(0.6 \%)\end{array}$ \\
\hline $\mathrm{C} 11$ & Malignant neoplasm of nasopharynx & $\begin{array}{c}1 \\
(0.3 \%)\end{array}$ \\
\hline $\mathrm{C} 16$ & Malignant neoplasm of stomach & $\begin{array}{c}1 \\
(0.3 \%)\end{array}$ \\
\hline $\mathrm{C} 18$ & Malignant neoplasm of colon & $\begin{array}{c}1 \\
(0.3 \%)\end{array}$ \\
\hline C41 & $\begin{array}{c}\text { Malignant neoplasm of bone and articular cartilage of } \\
\text { other and unspecified sites }\end{array}$ & $\begin{array}{c}1 \\
(0.3 \%)\end{array}$ \\
\hline C49 & Malignant neoplasm of other connective and soft tissue & $\begin{array}{c}1 \\
(0.3 \%)\end{array}$ \\
\hline $\mathrm{C} 50$ & Malignant neoplasm of breast & $\begin{array}{c}1 \\
(0.3 \%)\end{array}$ \\
\hline $\mathrm{C} 76$ & Malignant neoplasm of other and ill-defined sites & $\begin{array}{c}1 \\
(0.3 \%)\end{array}$ \\
\hline $\mathrm{C} 85$ & Other and unspecified types of non-Hodgkin lymphoma & $\begin{array}{c}1 \\
(0.3 \%)\end{array}$ \\
\hline
\end{tabular}

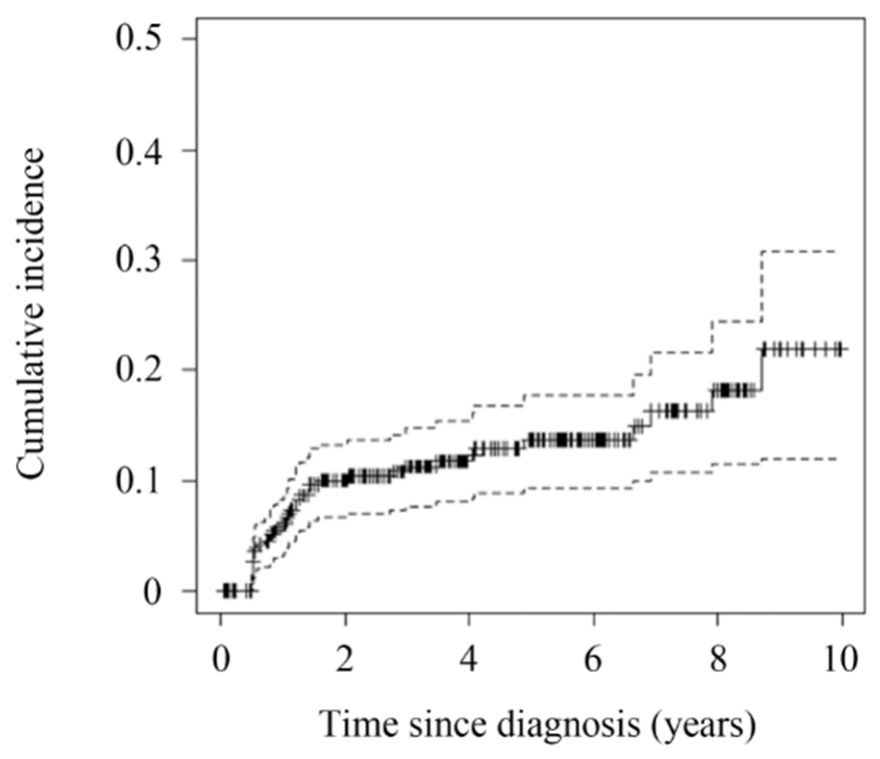

Figure 2. Cumulative incidence of second primary cancers in uveal melanoma patients.

\subsection{Risk Factors for SPC Development}

The associations of age, sex, and enucleation with the development of SPCs were examined. In 352 patients with uveal melanoma as their first cancer, the mean age was $56 \pm 14$ years, and $182(52 \%)$ were male. Among these patients, $115(33 \%)$ required enucleation during the follow-up period. SPCs developed in 43 (12\%) patients, and 44 (13\%) patients died. In the Cox models with and without the competing risk model, age was the only factor associated with SPC development (Table 4). Although the hazard ratios were higher for males and those with enucleation, the differences were not statistically significant. 
Table 3. Estimation of second primary cancer risk in uveal melanoma patients.

\begin{tabular}{|c|c|c|c|c|c|c|}
\hline \multirow[b]{2}{*}{$\begin{array}{l}\text { Age Group } \\
\text { (Year) }\end{array}$} & \multicolumn{3}{|c|}{$\begin{array}{l}2014 \text { Nationwide Statistics from The Korea Central } \\
\text { Cancer Registry }\end{array}$} & \multicolumn{3}{|c|}{$\begin{array}{c}\text { Incidence of Second Primary Cancers in Uveal } \\
\text { Melanoma Patients }\end{array}$} \\
\hline & $\begin{array}{l}\text { Population of } \\
\text { the Middle of } \\
\text { the Year }\end{array}$ & $\begin{array}{l}\text { All Cancers } \\
\text { (C00-C96) }\end{array}$ & $\begin{array}{c}\text { Incidence Rate } \\
\text { (Per } \\
\text { 100,000 Person) }\end{array}$ & Person-Years & $\begin{array}{c}\text { Number of } \\
\text { Patients with } \\
\text { SPC }\end{array}$ & $\begin{array}{c}\text { Expected Number } \\
\text { of Patients } \\
\text { Developing SPC }\end{array}$ \\
\hline $0-4$ & $2,297,243.5$ & 460 & 20 & 0 & 0 & 0 \\
\hline 5-9 & $2,308,229$ & 278 & 12 & 0 & 0 & 0 \\
\hline $10-14$ & $2,731,443$ & 353 & 12.9 & 0 & 0 & 0 \\
\hline 15-19 & $3,364,378.5$ & 673 & 20 & 8.353 & 0 & 0.002 \\
\hline $20-24$ & $3,433,785.5$ & 1224 & 35.6 & 17.268 & 0 & 0.006 \\
\hline $25-29$ & $3,151,400.5$ & 2409 & 76.4 & 25.131 & 0 & 0.019 \\
\hline $30-34$ & $3,971,975.5$ & 5363 & 135 & 61.949 & 0 & 0.084 \\
\hline $35-39$ & $3,875,142.5$ & 7993 & 206.3 & 59.003 & 0 & 0.122 \\
\hline $40-44$ & $4,509,393.5$ & 13,396 & 297.1 & 78.648 & 5 & 0.234 \\
\hline $45-49$ & $4,301,489.5$ & 16,937 & 393.7 & 140.290 & 5 & 0.552 \\
\hline $50-54$ & $4,322,181.5$ & 23,309 & 539.3 & 174.817 & 1 & 0.943 \\
\hline $55-59$ & $3,678,401.5$ & 25,826 & 702.1 & 191.617 & 7 & 1.345 \\
\hline $60-64$ & $2,521,163$ & 23,716 & 940.7 & 151.351 & 5 & 1.424 \\
\hline $65-69$ & $2,008,782$ & 24,625 & 1225.90 & 151.020 & 4 & 1.851 \\
\hline $70-74$ & $1,785,086.5$ & 27,961 & 1566.40 & 144.197 & 4 & 2.259 \\
\hline $75-79$ & $1,296,333.5$ & 23,273 & 1795.30 & 109.865 & 7 & 1.972 \\
\hline $80-84$ & 729,676 & 14,052 & 1925.80 & 33.139 & 4 & 0.638 \\
\hline$>85$ & 477,053 & 8283 & 1736.30 & 26.982 & 1 & 0.468 \\
\hline \multirow[t]{2}{*}{ Total } & $50,763,158.0$ & 220131 & 433.6 & 1373.629 & 43 & 11.919 \\
\hline & & & & \multicolumn{3}{|c|}{$\begin{array}{l}\text { SIR for second primary cancers in uveal melanoma: } 3.61 \\
\qquad(95 \% \mathrm{CI}, 2.61-4.86)\end{array}$} \\
\hline
\end{tabular}

SPC, second primary cancer; SIR, standardized incidence ratio.

Table 4. Factors associated with the development of second primary cancers.

\begin{tabular}{|c|c|c|c|c|c|c|c|c|}
\hline \multirow[b]{3}{*}{ Risk Factors } & \multicolumn{4}{|c|}{ Cox Model } & \multicolumn{4}{|c|}{ Cox Model with Competing Risk } \\
\hline & \multicolumn{2}{|c|}{ Univariate } & \multicolumn{2}{|c|}{ Multivariate } & \multicolumn{2}{|c|}{ Univariate } & \multicolumn{2}{|c|}{ Multivariate } \\
\hline & HR (95\% CI) & $p$-Value & HR $(95 \%$ CI $)$ & $p$-Value & HR $(95 \%$ CI $)$ & $p$-Value & HR $(95 \% \mathrm{CI})$ & $p$-Value \\
\hline Age & $\begin{array}{c}1.034 \\
(1.011,1.057)\end{array}$ & 0.003 & $\begin{array}{c}1.036 \\
(1.013,1.060)\end{array}$ & 0.002 & $\begin{array}{c}1.032 \\
(1.010,1.053)\end{array}$ & 0.003 & $\begin{array}{c}1.034 \\
(1.011,1.057)\end{array}$ & 0.003 \\
\hline Male & $\begin{array}{c}1.492 \\
(0.813,2.738)\end{array}$ & 1.196 & $\begin{array}{c}1.640 \\
(0.890,3.021)\end{array}$ & 0.112 & $\begin{array}{c}1.426 \\
(0.782,2.599)\end{array}$ & 0.247 & $\begin{array}{c}1.545 \\
(0.832,2.869)\end{array}$ & 0.168 \\
\hline Enucleation & $\begin{array}{c}1.456 \\
(0.776,2.732)\end{array}$ & 0.242 & $\begin{array}{c}1.475 \\
(0.787,2.767)\end{array}$ & 0.225 & $\begin{array}{c}1.433 \\
(0.784,2.618)\end{array}$ & 0.243 & $\begin{array}{c}1.493 \\
(0.824,2.702)\end{array}$ & 0.186 \\
\hline
\end{tabular}

End of study: 267 (75\%); Development of secondary primary cancers (SPCs): 43 (12\%); Death: 44 (12\%); HR, Hazard ratio.

\section{Discussion}

In a nationwide, population-based study, we showed that $>40 \%$ patients with uveal melanoma had one or more coexisting cancers. This is a higher rate than those in previous studies reporting that $\sim 20 \%$ patients with uveal melanoma had coexisting cancers $[20,21]$. The majority of those studies included patients from the 1960s to 1990s; however, the annual cancer incidence rate and the development of cancer screening methods have increased rapidly over the past 2-3 decades, which may explain the high rate of coexisting cancers identified in the present study. A recent study using the Surveillance, Epidemiology, and End Results database estimated that the long-term cumulative incidence of other primary cancers is $>40 \%$, which is similar to the results of our study [22].

The most frequently identified coexisting cancers or SPCs reported by previous studies conducted in white populations of uveal melanoma patients were skin melanoma, nonmelanoma skin cancer, and breast, kidney, and prostate cancers [20-23]. Our analysis showed that uveal melanoma is frequently accompanied by lung, liver, brain, breast, prostate, thyroid, and gastric cancers, all of which are common cancers in Korea. Breast and prostate cancers have also been reported frequently in previous studies in white 
populations, but the rates of these other cancers differ between previous reports and the present study. These differences in the type of coexisting cancers are thought to be due to racial or environmental factors. Disparities in cancer incidence by race/ethnicity are well established [28]. Melanoma and non-melanoma skin cancers are commonly diagnosed in Caucasian but are rare in Asians [29]. Lung cancer among never smokers is increasing in East Asians, and East Asians harboring EGFR gene mutation are far more likely to be diagnosed with lung cancer [28,30]. Long-term exposure to particulate matter may also contribute to the development of lung cancer in Korea. Ambient fine particles are also associated with increased risk of breast, liver, and pancreatic cancers, which are frequently observed co-existing cancers in our study [31]. In terms of gastric cancers, these cancers more frequently and at an earlier age in Asians than in Caucasians, which can ascribed to dietary habits and Helicobacter pyroli infection [28,32,33].

Intriguingly, uveal melanoma was found to be frequently accompanied by lymphoma. Few studies have confirmed an association between lymphoma and uveal melanoma, but an association between non-Hodgkin lymphoma and skin melanoma was suggested, with the underlying mechanisms involving exposure to ultraviolet irradiation, commonly shared genetic aberrations, and immune perturbations associated with chemotherapy or comorbidities [34-40]. A recent large-scale study of $>40,000$ non-Hodgkin lymphoma patients confirmed that chemotherapy involving fludarabine and $\mathrm{T}$ cell activating autoimmune diseases increase the risk of melanoma in non-Hodgkin lymphoma [40]. Our findings suggest that uveal melanoma may also be associated with non-Hodgkin lymphoma. Recent studies have shown that GNAQ mutations appear repeatedly in certain types of non-Hodgkin lymphoma, and other studies have suggested that MYC alterations are associated with aggressive non-Hodgkin lymphoma or a poor prognosis of uveal melanoma [41-43]. In addition, both skin melanoma and uveal melanoma arise from the melanocytes derived from the neural crest, and therefore, immune perturbations may also promote tumorigenesis in uveal melanoma [44]. Further studies are needed to determine whether the incidence of uveal melanoma is actually increased in NHL survivors and to identify the associated risk factors.

This study also analyzed the occurrence of SPCs in addition to coexisting cancers. During the study period, $12 \%$ of patients developed SPCs, and the estimated 10-year cumulative incidence was $22 \%$, which was similar to previous studies [22,23]. The calculated SIR in this study was higher than those in previous studies, which was likely due to a number of differences. First, the mean age at onset of uveal melanoma in the Asian populations is the mid-50s, which is significantly younger than the age at onset in white populations. In a previous population-based study, patients diagnosed with uveal melanoma as their first cancer before the age of 50 years had an elevated SPC risk [22]. Second, in Korea, because cancer patients receive a reduction in medical expenses, patients diagnosed with their first cancer undergo more systematic examination, and second cancers may be identified more frequently as a result. Among the risk factors that were evaluated, age was associated with the development of SPCs, with an HR similar to those of previous studies. Male sex and enucleation also increased the HR for SPC, but these associations were not statistically significant.

The main limitations of our study were its retrospective nature and the limitations inherently associated with using a publicly available database. We were unable to include genetic and lifestyle risk factors (e.g., smoking) in the analyses. In addition, as the analysis was conducted based on ICD-10 codes, so the detailed molecular characteristics of the cancers were unknown. Despite these limitations, our data can be regarded as reliable because we defined cancers using both ICD-10 codes and the codes for expanding benefit coverage.

In conclusion, coexisting cancers were observed in more than $40 \%$ of patients with uveal melanoma, and associations with lung cancer, liver cancer, and non-Hodgkin lymphoma were confirmed. The incidence of SPCs was 3.61 times higher in uveal melanoma patients than in the reference population. Our findings will be useful in providing counseling for cancer screening in uveal melanoma patients. 
Author Contributions: Conceptualization, Y.J.K., I.J. and C.S.L.; methodology, Y.J.K., M.L., E.H.K. and I.J.; formal analysis, Y.J.K., M.L. and E.H.K.; writing-original draft preparation, Y.J.K. and M.L.; writing-review and editing, Y.J.K., M.L., E.H.K., I.J. and C.S.L. All authors have read and agreed to the published version of the manuscript.

Funding: This work was supported by the National Research Foundation of Korea (NRF) grant funded by the Korean government (MSIT). (No. 2019R1A2C2002393). This research was also supported by Basic Science Research Program through the National Research Foundation of Korea (NRF) funded by the Ministry of Education (2017R1A6A3A110335). The funding organization had no role in the design or conduct of this research.

Institutional Review Board Statement: The study was conducted according to the guidelines of the Declaration of Helsinki and was approved by the Institutional Review Board (IRB)/Ethics Committee of Severance Hospital, Yonsei University Health System (IRB No. 4-2019-0618).

Informed Consent Statement: The Institutional Review Board (IRB)/Ethics Committee waived the requirement for informed patient consent due to the retrospective study design and use of de-identified data.

Data Availability Statement: The data presented in this study are available upon request from the corresponding author.

Conflicts of Interest: The authors declare no conflict of interest.

\section{References}

1. Krantz, B.A.; Dave, N.; Komatsubara, K.M.; Marr, B.P.; Carvajal, R.D. Uveal melanoma: Epidemiology, etiology, and treatment of primary disease. Clin. Ophthalmol. 2017, 11, 279-289. [CrossRef] [PubMed]

2. McLaughlin, C.C.; Wu, X.C.; Jemal, A.; Martin, H.J.; Roche, L.M.; Chen, V.W. Incidence of noncutaneous melanomas in the U.S. Cancer 2005, 103, 1000-1007. [CrossRef] [PubMed]

3. Carvajal, R.D.; Piperno-Neumann, S.; Kapiteijn, E.; Chapman, P.B.; Frank, S.; Joshua, A.M.; Piulats, J.M.; Wolter, P.; Cocquyt, V.; Chmielowski, B.; et al. Selumetinib in Combination with Dacarbazine in Patients with Metastatic Uveal Melanoma: A Phase III, Multicenter, Randomized Trial (SUMIT). J. Clin. Oncol. 2018, 36, 1232-1239. [CrossRef] [PubMed]

4. Carvajal, R.D.; Sosman, J.A.; Quevedo, J.F.; Milhem, M.M.; Joshua, A.M.; Kudchadkar, R.R.; Linette, G.P.; Gajewski, T.F.; Lutzky, J.; Lawson, D.H.; et al. Effect of selumetinib vs chemotherapy on progression-free survival in uveal melanoma: A randomized clinical trial. JAMA 2014, 311, 2397-2405. [CrossRef] [PubMed]

5. Chen, X.; Wu, Q.; Depeille, P.; Chen, P.; Thornton, S.; Kalirai, H.; Coupland, S.E.; Roose, J.P.; Bastian, B.C. RasGRP3 Mediates MAPK Pathway Activation in GNAQ Mutant Uveal Melanoma. Cancer Cell 2017, 31, 685-696.e6. [CrossRef]

6. $\quad$ Feng, X.; Degese, M.S.; Iglesias-Bartolome, R.; Vaque, J.P.; Molinolo, A.A.; Rodrigues, M.; Zaidi, M.R.; Ksander, B.R.; Merlino, G.; Sodhi, A.; et al. Hippo-independent activation of YAP by the GNAQ uveal melanoma oncogene through a trio-regulated rho GTPase signaling circuitry. Cancer Cell 2014, 25, 831-845. [CrossRef]

7. Yu, F.X.; Luo, J.; Mo, J.S.; Liu, G.; Kim, Y.C.; Meng, Z.; Zhao, L.; Peyman, G.; Ouyang, H.; Jiang, W.; et al. Mutant Gq/11 promote uveal melanoma tumorigenesis by activating YAP. Cancer Cell 2014, 25, 822-830. [CrossRef]

8. Carvajal, R.D.; Schwartz, G.K.; Tezel, T.; Marr, B.; Francis, J.H.; Nathan, P.D. Metastatic disease from uveal melanoma: Treatment options and future prospects. Br. J. Ophthalmol. 2017, 101, 38-44. [CrossRef]

9. Aronow, M.E.; Topham, A.K.; Singh, A.D. Uveal Melanoma: 5-Year Update on Incidence, Treatment, and Survival (SEER 1973-2013). Ocul. Oncol. Pathol. 2018, 4, 145-151. [CrossRef]

10. Boffetta, P.; Hashibe, M.; La Vecchia, C.; Zatonski, W.; Rehm, J. The burden of cancer attributable to alcohol drinking. Int. J. Cancer 2006, 119, 884-887. [CrossRef]

11. Morton, L.M.; Onel, K.; Curtis, R.E.; Hungate, E.A.; Armstrong, G.T. The rising incidence of second cancers: Patterns of occurrence and identification of risk factors for children and adults. Am. Soc. Clin. Oncol. Educ. Book 2014, e57-e67. [CrossRef]

12. Morton, L.M.; Swerdlow, A.J.; Schaapveld, M.; Ramadan, S.; Hodgson, D.C.; Radford, J.; van Leeuwen, F.E. Current knowledge and future research directions in treatment-related second primary malignancies. EJC Suppl. 2014, 12, 5-17. [CrossRef]

13. Oeffinger, K.C.; Baxi, S.S.; Novetsky Friedman, D.; Moskowitz, C.S. Solid tumor second primary neoplasms: Who is at risk, what can we do? Semin. Oncol. 2013, 40, 676-689. [CrossRef]

14. Vineis, P.; Alavanja, M.; Buffler, P.; Fontham, E.; Franceschi, S.; Gao, Y.T.; Gupta, P.C.; Hackshaw, A.; Matos, E.; Samet, J.; et al. Tobacco and cancer: Recent epidemiological evidence. J. Natl. Cancer Inst. 2004, 96, 99-106. [CrossRef]

15. Giardiello, F.M.; Krush, A.J.; Petersen, G.M.; Booker, S.V.; Kerr, M.; Tong, L.L.; Hamilton, S.R. Phenotypic variability of familial adenomatous polyposis in 11 unrelated families with identical APC gene mutation. Gastroenterology 1994, 106, 1542-1547. [CrossRef]

16. Hes, F.J.; Nielsen, M.; Bik, E.C.; Konvalinka, D.; Wijnen, J.T.; Bakker, E.; Vasen, H.F.; Breuning, M.H.; Tops, C.M. Somatic APC mosaicism: An underestimated cause of polyposis coli. Gut 2008, 57, 71-76. [CrossRef] [PubMed] 
17. Soravia, C.; Berk, T.; Madlensky, L.; Mitri, A.; Cheng, H.; Gallinger, S.; Cohen, Z.; Bapat, B. Genotype-phenotype correlations in attenuated adenomatous polyposis coli. Am. J. Hum. Genet. 1998, 62, 1290-1301. [CrossRef] [PubMed]

18. Burke, W.; Daly, M.; Garber, J.; Botkin, J.; Kahn, M.J.; Lynch, P.; McTiernan, A.; Offit, K.; Perlman, J.; Petersen, G.; et al. Recommendations for follow-up care of individuals with an inherited predisposition to cancer. II. BRCA1 and BRCA2. Cancer Genetics Studies Consortium. JAMA 1997, 277, 997-1003. [CrossRef]

19. Nelson, H.D.; Pappas, M.; Cantor, A.; Haney, E.; Holmes, R. Risk Assessment, Genetic Counseling, and Genetic Testing for BRCA-Related Cancer in Women: Updated Evidence Report and Systematic Review for the US Preventive Services Task Force. JAMA 2019, 322, 666-685. [CrossRef]

20. Bergman, L.; Nilsson, B.; Ragnarsson-Olding, B.; Seregard, S. Uveal melanoma: A study on incidence of additional cancers in the Swedish population. Investig. Ophthalmol. Vis. Sci. 2006, 47, 72-77. [CrossRef]

21. Callejo, S.A.; Al-Khalifa, S.; Ozdal, P.C.; Edelstein, C.; Burnier, M.N., Jr. The risk of other primary cancer in patients with uveal melanoma: A retrospective cohort study of a Canadian population. Can. J. Ophthalmol. 2004, 39, 397-402. [CrossRef]

22. Lains, I.; Bartosch, C.; Mondim, V.; Healy, B.; Kim, I.K.; Husain, D.; Miller, J.W. Second Primary Neoplasms in Patients with Uveal Melanoma: A SEER Database Analysis. Am. J. Ophthalmol. 2016, 165, 54-64. [CrossRef]

23. Diener-West, M.; Reynolds, S.M.; Agugliaro, D.J.; Caldwell, R.; Cumming, K.; Earle, J.D.; Hawkins, B.S.; Hayman, J.A.; Jaiyesimi, I.; Kirkwood, J.M.; et al. Second primary cancers after enrollment in the COMS trials for treatment of choroidal melanoma: COMS Report No. 25. Arch. Ophthalmol. 2005, 123, 601-604. [CrossRef] [PubMed]

24. Kim, J.A.; Yoon, S.; Kim, L.Y.; Kim, D.S. Towards Actualizing the Value Potential of Korea Health Insurance Review and Assessment (HIRA) Data as a Resource for Health Research: Strengths, Limitations, Applications, and Strategies for Optimal Use of HIRA Data. J. Korean Med. Sci. 2017, 32, 718-728. [CrossRef] [PubMed]

25. Kim, S.; Kwon, S. The effect of extension of benefit coverage for cancer patients on health care utilization across different income groups in South Korea. Int. J. Health Care Financ. Econ. 2014, 14, 161-177. [CrossRef] [PubMed]

26. Korea Central Cancer Registry, Ministry of Health and Welfare (South Korea), National Cancer Center (South Korea). South Korea-Annual Report of Cancer Statistics in Korea in 2014; National Cancer Center (South Korea): Goyang-si, Korea, 2016.

27. Fine, J.P.; Gray, R.J. A proportional hazards model for the subdistribution of a competing risk. J. Am. Stat. Assoc. 1999, 94, 496-509. [CrossRef]

28. Zavala, V.A.; Bracci, P.M.; Carethers, J.M.; Carvajal-Carmona, L.; Coggins, N.B.; Cruz-Correa, M.R.; Davis, M.; de Smith, A.J.; Dutil, J.; Figueiredo, J.C.; et al. Cancer health disparities in racial/ethnic minorities in the United States. Br. J. Cancer 2021, 124, 315-332. [CrossRef]

29. Oh, C.M.; Cho, H.; Won, Y.J.; Kong, H.J.; Roh, Y.H.; Jeong, K.H.; Jung, K.W. Nationwide Trends in the Incidence of Melanoma and Non-melanoma Skin Cancers from 1999 to 2014 in South Korea. Cancer Res. Treat. 2018, 50, 729-737. [CrossRef]

30. Kosaka, T.; Yatabe, Y.; Endoh, H.; Kuwano, H.; Takahashi, T.; Mitsudomi, T. Mutations of the epidermal growth factor receptor gene in lung cancer: Biological and clinical implications. Cancer Res. 2004, 64, 8919-8923. [CrossRef]

31. Wong, C.M.; Tsang, H.; Lai, H.K.; Thomas, G.N.; Lam, K.B.; Chan, K.P.; Zheng, Q.; Ayres, J.G.; Lee, S.Y.; Lam, T.H.; et al. Cancer Mortality Risks from Long-term Exposure to Ambient Fine Particle. Cancer Epidemiol. Biomark. Prev. 2016, 25, 839-845. [CrossRef]

32. Lott, P.C.; Carvajal-Carmona, L.G. Resolving gastric cancer aetiology: An update in genetic predisposition. Lancet Gastroenterol. Hepatol. 2018, 3, 874-883. [CrossRef]

33. Balakrishnan, M.; George, R.; Sharma, A.; Graham, D.Y. Changing Trends in Stomach Cancer throughout the World. Curr. Gastroenterol. Rep. 2017, 19, 36. [CrossRef] [PubMed]

34. Lens, M.B.; Newton-Bishop, J.A. An association between cutaneous melanoma and non-Hodgkin's lymphoma: Pooled analysis of published data with a review. Ann. Oncol. 2005, 16, 460-465. [CrossRef] [PubMed]

35. Travis, L.B.; Curtis, R.E.; Boice, J.D., Jr.; Hankey, B.F.; Fraumeni, J.F., Jr. Second cancers following non-Hodgkin's lymphoma. Cancer 1991, 67, 2002-2009. [CrossRef]

36. Travis, L.B.; Curtis, R.E.; Glimelius, B.; Holowaty, E.; Van Leeuwen, F.E.; Lynch, C.F.; Adami, J.; Gospodarowicz, M.; Wacholder, S.; Inskip, P.; et al. Second cancers among long-term survivors of non-Hodgkin's lymphoma. J. Natl. Cancer Inst. 1993, 85, 1932-1937. [CrossRef]

37. Dong, C.; Hemminki, K. Second primary neoplasms among 53159 haematolymphoproliferative malignancy patients in Sweden, 1958-1996: A search for common mechanisms. Br. J. Cancer 2001, 85, 997-1005. [CrossRef]

38. McKenna, D.B.; Stockton, D.; Brewster, D.H.; Doherty, V.R. Evidence for an association between cutaneous malignant melanoma and lymphoid malignancy: A population-based retrospective cohort study in Scotland. Br. J. Cancer 2003, 88, 74-78. [CrossRef]

39. Royle, J.S.; Baade, P.; Joske, D.; Fritschi, L. Risk of second cancer after lymphohematopoietic neoplasm. Int. J. Cancer 2011, 129, 910-919. [CrossRef]

40. Lam, C.J.; Curtis, R.E.; Dores, G.M.; Engels, E.A.; Caporaso, N.E.; Polliack, A.; Warren, J.L.; Young, H.A.; Levine, P.H.; Elmi, A.F.; et al. Risk Factors for Melanoma Among Survivors of Non-Hodgkin Lymphoma. J. Clin. Oncol. 2015, 33, 3096-3104. [CrossRef]

41. Li, Z.; Zhang, X.; Xue, W.; Zhang, Y.; Li, C.; Song, Y.; Mei, M.; Lu, L.; Wang, Y.; Zhou, Z.; et al. Recurrent GNAQ mutation encoding T96S in natural killer/T cell lymphoma. Nat. Commun. 2019, 10, 4209. [CrossRef]

42. Ott, G.; Rosenwald, A.; Campo, E. Understanding MYC-driven aggressive B-cell lymphomas: Pathogenesis and classification. Blood 2013, 122, 3884-3891. [CrossRef] 
43. Kim, Y.J.; Park, S.J.; Maeng, K.J.; Lee, S.C.; Lee, C.S. Multi-Platform Omics Analysis for Identification of Molecular Characteristics and Therapeutic Targets of Uveal Melanoma. Sci. Rep. 2019, 9, 19235. [CrossRef] [PubMed]

44. Shors, A.R.; Iwamoto, S.; Doody, D.R.; Weiss, N.S. Relationship of uveal and cutaneous malignant melanoma in persons with multiple primary tumors. Int. J. Cancer 2002, 102, 266-268. [CrossRef] [PubMed] 